\title{
DIREITO FUNDAMENTAL À EDUCAÇÃO, EXTRAFISCALIDADE E FEDERALISMO DE COOPERAÇÃO: "ICMS EDUCACIONAL" BASEADO EM INVESTIMENTO MUNICIPAL
}

\author{
FUNDAMENTAL RIGHT TO EDUCATION, FISCAL POLICIES, TAX EXPENDITURES \\ AND COOPERATIVE FEDERALISM: ICMS TAX REVENUE TRANSFERS TO \\ EDUCATION BASED ON MUNICIPAL INVESTMENT
}

Caio Gama Mascarenhas

\begin{abstract}
Mestrado em Direito pela Universidade Federal de Mato Grosso do Sul em andamento (2018-presente). Graduado pela Pontifícia Universidade Católica de Goiás PUC-GO (2009) e especializado em Direito Constitucional e Administrativo pela mesma instituição (2013). Participou do grupo de assessoramento de gabinete de ministro do Superior

Tribunal de Justiça atuante na $2^{\mathrm{a}}$ turma de Direito Público (2014-2015). Integrante do grupo de Pesquisas no CNPq - Direito, Políticas Públicas e Desenvolvimento Sustentável. Procurador do Estado do Mato Grosso do Sul (2015- presente).

E-mail: caiogm_jus@live.com
\end{abstract}

Lídia Maria Ribas

Mestre e Doutora em Direito do Estado pela Pontifícia Universidade Católica - PUC/SP. Pós-doutorado na Faculdade de Direito da Universidade de Coimbra em Direito Público; pela Universidade Nova de Lisboa e pela Universidade do Museo Social da Argentina em

Ciências Jurídicas e Sociais. Pesquisadora, professora e orientadora na graduação e na pós-graduação da Universidade Federal de Mato Grosso do Sul e da Universidade para o

Desenvolvimento do Estado e da Região do Pantanal. Grupo de Pesquisas no CNPq -

Direito, Políticas Públicas e Desenvolvimento Sustentável. Membro da Academia de

Direito Tributário e do CEDIS/UNL. E-mail: limaribas@uol.com.br

Recebido em: 11/12/2017

Aprovado em: 31/04/2018

RESUMO: Esse trabalho versa sobre a extrafiscalidade como instrumento indutor de investimentos nos ensinos públicos básico, fundamental e médio - visando à maximização do direito fundamental à educação de qualidade (art. 206, VII, CF). Por ser um estudo descritivo e analítico, é baseado em pesquisas bibliográfica, legislativa e documental, utilizando-se dos métodos dedutivo e indutivo. O trabalho visa fornecer bases teóricas e proposições legislativas para: a) atrair investimentos para o ensino público escolar de forma eficaz; b) incentivar municípios a envidarem maiores esforços no ensino público local; c) incentivar a participação da comunidade local no ensino escolar público; e d) melhorar a estrutura e qualidade da educação pública.Ao longo do trabalho, abordam-se: análise do direito fundamental à educação de qualidade; extrafiscalidade como instrumento de desenvolvimento sustentável; a relação entre extrafiscalidade, ensino de qualidade e desenvolvimento; e a extrafiscalidade e o federalismo de cooperação como instrumentos de indução de investimentos locais no ensino público escolar, na forma de repasses de ICMS, audiências públicas e normas de renúncia de receitas.

Palavras-chave: Educação pública.Renúncia de receitas.Desenvolvimento sustentável.Políticas públicas.Direito fundamental. 
ABSTRACT: This study shows fiscal policies (including tax expenditures) as instruments of investment inducement on public schools, with the scope of optimizing the fundamental right of quality education (art. 206, VII, of Brazilian Federal Constitution). Because this is a descriptive and analitic survey, it will be conducted based on bibliographical, legislative and documental research, using both inductive and deductive methods. This paper aims to provide theoretical bases and legislative proposals to: a) attract investments to public school education in an effective way; b) encourage municipalities to make greater efforts in local public education; c) encourage the participation of the local community in public school education; and d) improve the structure and quality of public education. This work assesses: the fundamental right of quality education; fiscal policies as an instrument of sustainable development; and fiscal policies and cooperative federalism as inducing instruments of investments on public schools, especially ICMS constitutional transfers, public hearings and tax expenditures standards.

Keywords: Public education. Tax expenditures. Sustainable development. Public policies. Fundamental right.

SUMÁRIO: Introdução; 1. Educação universal de qualidade: direito fundamental enquanto liberdade pública e direito social; 2.A ordem econômica constitucional sob o aspecto da extrafiscalidade e do desenvolvimento sustentável; 3.Extrafiscalidade, ensino de qualidade e desenvolvimento; 4.Federalismo de cooperação, extrafiscalidade e ICMS educacional: indução de investimento no ensino público escolar e poder público municipal; Notas conclusivas; Referências bibliográficas.

\section{INTRODUÇÃO}

Os problemas na área da educação pública são conhecidos no cenário brasileiro. $\mathrm{O}$ acesso à educação no ensino escolar público, embora expandido nas últimas décadas, ainda atinge níveis insatisfatórios.

A discussão acerca da qualidade do ensino nas escolas públicas é ainda mais complexa. A questão do respeito aos padrões de qualidade (inciso VII do art. 206 da Constituição) é um dos maiores anseios da sociedade, fazendo parte do rol de preocupações de especialistas da área da pedagogia, economia e gestão pública. A qualidade do ensino possui notável apelo popular, sendo utilizado frequentemente como tema de debates políticos e eleitorais. Tal questão, no entanto, parece ter simultaneamente contornos nacionais, regionais e locais.

É um equívoco dizer que, no Brasil, todas as instituições de ensino público básico, fundamental e médio encontram-se na mesma situação. Os resultados das avaliações de qualidade de ensino público variam consideravelmente quando se faz uma pesquisa comparativa em âmbitos regional e local.

Considerando a premissa de que os problemas estruturais de ensino variam conforme cada região ou localidade, necessita-se de pensar em políticas públicas de caráter regional e local, mediante o federalismo de cooperação.

A administração pública, em geral, tem se mostrado ineficiente na tarefa de prestar um serviço público de ensino de qualidade. Uma das saídas para tal ineficiência é a instituição de sistemas de colaboração com a sociedade. No caso, a extrafiscalidade possuiria o escopo de induzir um regime de colaboração da sociedade com o ensino público escolar.

Considerando o atual grau de desenvolvimento social brasileiro e a importância dos ensinos escolares básico, fundamental e médio enquanto garantias de padrões mínimos de dignidade humana, o presente trabalho não prioriza os investimentos no ensino superior. Não se nega a importância do ensino superior para o desenvolvimento do país, mas esse resta prejudicado quando a educação básica (que lhe precede) encontra-se em condições precárias. 
Objetiva-seanalisar o fenômeno da extrafiscalidade e federalismo de cooperação na área da educação com o escopo de: a) atrair investimentos para o ensino público escolar de forma eficaz; b) incentivar municípios a envidarem maiores esforços no ensino público local; c) incentivar a participação da comunidade localno ensino escolar público; e d) melhorar a estrutura e qualidade da educação pública.

Ao longo do texto, abordam-se: análise do direito fundamental à educação de qualidade; extrafiscalidade como instrumento de desenvolvimento sustentável; a relação entre extrafiscalidade, ensino de qualidade e desenvolvimento; e a extrafiscalidade e o federalismo de cooperação como instrumentos de indução de investimentos locais no ensino público escolar, na forma de repasses de ICMS (ICMS educacional), audiências públicas e normas de renúncia de receitas.

\section{EDUCAÇÃO UNIVERSAL DE QUALIDADE: DIREITO FUNDAMENTAL ENQUANTO LIBERDADE PÚBLICA E DIREITO SOCIAL}

Diferentemente da liberdade e igualdade formal ${ }^{1}$, o direito à educação - enquanto direito da pessoa humana e obrigação do Estado e sociedade - não possui a mesma proteção histórica da doutrina jus naturalista, sendo uma construção teórica mais recente ${ }^{2}$. Inicialmente, o direito à instrução era um mero valor abstrato em posição suspensa (dimensão pré-sóciojurídica). A partir do momento em que tal valor (a educação) passou a fazer parte do sentimento axiológico da sociedade, começou a existir na realidade social. Após adentrar o interesse social, incumbiu ao direito proteger e garantir ${ }^{3}$ a educação mediante a sua inclusão no ordenamento jurídico ${ }^{4}$.

No plano internacional, a Declaração Universal de Direitos Humanos de 1948 (DUDH) já concebia o direito à instrução na sua conotação clássica individual, acoplando-lhe, também, uma finalidade social. Conforme o art. 26 da Declaração:

\footnotetext{
1 "Segundo Locke, o verdadeiro estado do homem não é o estado civil, mas o natural, ou seja, o estado de natureza no qual os homens são livres e iguais, sendo o estado civil uma criação artificial, que não tem outra meta além da de permitir a mais ampla explicitação da liberdade e da igualdade naturais. Ainda que a hipótese do estado de natureza tenha sido abandonada, as primeiras palavras com as quais se abre a Declaração Universal dos Direitos do Homem conservam um claro eco de tal hipótese: 'Todos os homens nascem livres e iguais em dignidade e direitos.' O que é uma maneira diferente de dizer que os homens são livres e iguais por natureza" (BOBBIO, 1992, p. 18).

2 "Não existe atualmente nenhuma carta de direitos, para darmos um exemplo convincente, que não reconheça o direito à instrução - crescente, de resto, de sociedade para sociedade —, primeiro elementar, depois secundária, e pouco a pouco até mesmo universitária. Não me consta que, nas mais conhecidas descrições do estado de natureza, esse direito fosse mencionado. A verdade é que esse direito não fora posto no estado de natureza porque não emergira na sociedade da época em que nasceram as doutrinas jus naturalistas, quando as exigências fundamentais que partiam daquelas sociedades para chegarem aos poderosos da Terra eram principalmente exigências de liberdade em face das Igrejas e dos Estados, e não ainda de outros bens, como o da instrução, que somente uma sociedade mais evoluída econômica e socialmente poderia expressar. Tratava-se de exigências cuja finalidade era principalmente pôr limites aos poderes opressivos; e, sendo assim, a hipótese de um estado pré-estatal, ou de um estado liberto de poderes supra-individuaís, como os das Igrejas e dos governos políticos, correspondia perfeitamente à finalidade de justificar a redução, aos seus mínimos termos, do espaço ocupado por tais poderes, e de ampliar os espaços de liberdade dos indivíduos" (BOBBIO, 1992, p. 36).

${ }^{3}$ A esse processo foi dado o nome de dinamogenesis. Nos dizeres de Vladmir da Silveira e Maria Rocasolano (2010, p. 196): "Por intermédio da normatização, os valores, que já são, vivem. Saltam do plano ideal (sentimental) para o real (normatizado) porque se pode exigi-los, garanti-los e protegê-los. Pode-se dizer então que o sentimento axiológico é uma ordem valorativa que a sociedade estima como valiosa, define e, por essa razão, sente - e em caso de perigo defenderá apaixonadamente.".

${ }^{4}$ Murray Rothbard destaca que a educação escolar obrigatória, enquanto instituição estatal, originou-se na Prússia, em 1717. Emsuaspalavras(1979, p. 25): “Itwas King Frederick William I who inaugurated the Prussian compulsory school system, the first national system in Europe. In 1717, he ordered compulsory attendance of all children at the state schools, and, in later acts, he followed with the provision for the construction of more such schools".
}

Revista de Direito Brasileira | São Paulo, SP | v. 19 | n. 8 | p. 84 - 106 |Jan./Abr. 2018 
1. Todo ser humano tem direito à instrução. A instrução será gratuita, pelo menos nos graus elementares e fundamentais. A instrução elementar será obrigatória. A instrução técnico-profissional será acessível a todos, bem como a instrução superior, esta baseada no mérito. 2. A instrução será orientada no sentido do pleno desenvolvimento da personalidade humana e do fortalecimento do respeito pelos direitos humanos e pelas liberdades fundamentais. A instrução promoverá a compreensão, a tolerância e a amizade entre todas as nações e grupos raciais ou religiosos, e coadjuvará as atividades das Nações Unidas em prol da manutenção da paz. 3. Os pais têm prioridade de direito na escolha do gênero de instrução que será ministrada a seus filhos(ASSEMBLEIA GERAL DA ONU, 1948, p. 14).

Nesse sentido, defende-se que atualmente o direito à educação apresenta duas faces:cuida-se de direito fundamental que é simultaneamente de primeira e segunda dimensões, denotando uma realidade individual e social. A educação, portanto, englobaria: o direito à instrução como um processo de desenvolvimento individual; o direito a uma política educacional; e uma obrigatória coparticipação dos pais e da sociedade no processo educacional (CAGGIANO, 2009, p. 23). Em razão do alto grau de fundamentalidade do direito à educação, vindica-se, inclusive, a sua posição dentro do mínimo existencial do indivíduo enquanto tutela de sua dignidade humana 5 .

No plano interno, a Constituição brasileira (BRASIL, 1988) incorporou os preceitos básicos do art. 26 da Declaração Universal de Direitos Humanos nos seguintes dispositivos: a) definir o dever do Estado e família com a educação (art. 205); b) dever de incentivar a educação com a colaboração da sociedade (art. 205); c) dever de instrução do indivíduo, visando o pleno desenvolvimento da pessoa, enquanto cidadã e trabalhadora qualificada (art. 205); d) comprometimento do Estado com o desenvolvimento nacional e com a construção de uma sociedade justa e solidária (art. $3^{\circ}$ ); e) direito subjetivo de acesso ao ensino obrigatório e gratuito (art. 208, § $1^{\circ}$ ); e f) deveres de universalização e igualdade de ensino (art. 206). Ressalta-se a fundamentalidade material de tais normas, permitindo, por consequência lógica, a sua classificação como cláusulas pétreas.

No campo do direito a prestações estatais de serviços de educação, denota-se a questão do acesso ao ensino médio e superior. Diferentemente do ensino fundamental e do direito à educação infantil, o inciso II do artigo 208 da Constituição prevê a garantia da "progressiva

\footnotetext{
${ }^{5}$ Sobre a força normativa do direito fundamental a educação em face da alegação estatal de ausência de recursos, Ingo Sarlet tece alguns comentários (2015, p. 285): “Com apoio na argumentação desenvolvida, parecem-nos viáveis, ao menos em princípio, as alternativas sugeridas por Luís R. Barroso, que, na hipótese de não ser possível o reconhecimento de um direito de acesso ao ensino fundamental público gratuito, no caso de inexistentes ou comprovadamente insuficientes os recursos materiais disponíveis (escolas, salas de aula, vagas, professores etc.), considera possível a condenação do poder público, numa demanda de natureza cominatória, a uma obrigação de fazer, por exemplo, a construção de uma escola, ou mesmo a matrícula em escola particular às expensas do poder público, restando, ainda, a insatisfatória possibilidade de exigir-se do Estado o pagamento de uma indenização pela omissão, que, no entanto - como bem reconhece o autor - não tem o condão de substituir adequadamente a falta de estudo. Além dos argumentos já colacionados, verifica-se que um direito subjetivo (inclusive originário) a prestações em matéria educacional, especialmente no campo do ensino fundamental, situa-se na esfera da garantia do mínimo existencial, especialmente naquilo em que este, como já sinalado no capítulo próprio, abrange uma dimensão sociocultural e não se limita a um mínimo vital, fundamentação amplamente prestigiada na doutrina e jurisprudência, inclusive do STF, situações que abrangem o reconhecimento de um direito subjetivo de acesso à educação infantil em creches disponibilizadas pelo poder público para crianças de até cinco anos de idade".

${ }^{6}$ Ingo Sarlet defende que muitos dos princípios do art. 206 possuem contornos de direitos subjetivos fundamentais, por força do art. $5^{\circ}, \S 2^{\circ}$, da Carta Magna, consagrando o princípio da abertura material do catálogo dos direitos fundamentais da nossa Constituição (2015, p. 285). Na seara tributária, um exemplo de tal abertura seria o princípio da anterioridade consagrado no art. 150, inc. III, alínea b, da CF, que - na decisão do Supremo Tribunal Federal na ADI n ${ }^{\circ}$ 939-7 - foi reconhecido como autêntico direito e garantia fundamental do cidadão-contribuinte.
}

Revista de Direito Brasileira | São Paulo, SP | v. 19 | n. 8 | p. 84- 106 |Jan./Abr. 2018 
universalização do ensino médio gratuito". Em relação ao ensino superior, assegura-se o "acesso aos níveis mais elevados do ensino e da pesquisa e da criação artística, segundo a capacidade de cada um" (artigo 208, V). O texto da Carta não previu, de forma expressa, direito subjetivo a uma vaga no ensino médio gratuito nem direito à vaga em Instituição de Ensino Superior mantida pelo poder público (SARLET, 2015, p. 288).

Em relação ao direito subjetivo a uma vaga em instituição pública no ensino médio, são vastos os argumentos para considerá-lo um dever prestacional do estado. No plano interno brasileiro, reconheceu-se a vontade do Poder Constituinte de atingir a universalização do ensino médio gratuito - uma vez atingida, seria notória a existência de um direito subjetivo. Outro fator que denota isso é o inciso I do art. 208 da CF, que determina educação básica obrigatória dos 4 aos 17 anos - sendo que esse limite máximo de idade coincide com a idade média dos alunos que concluem o ensino médio ${ }^{7}$. Logo, se o direito não se encontra expresso na Constituição Federal em um primeiro momento, seria, no mínimo, uma decorrência lógica dos princípios adotados pela constituição Federal conforme o art. $5^{\circ}, \S 2^{\circ}$, da Carta. Ressalta-se a essencialidade do ensino médio para o ingresso da pessoa no mercado de trabalho e para o acesso aos níveis superiores de ensino.

Considera-se, ainda, a importância do ensino médio no contexto das crescentes demandas de formação num mundo complexo e marcado pela utilização da tecnologia. Destacase a sua relevância para o exercício efetivo do direito ao livre desenvolvimento da personalidade e garantia de níveis de autonomia significativos para o indivíduo. O dever de progressividade previsto no inciso II do artigo 208 da CF deve, portanto, ser entendido em sua eficácia normativa constitucional. Um descumprimento injustificado da meta da progressiva universalização do ensino médio gratuito gera o reconhecimento de um direito subjetivo a uma vaga na rede pública ou, ainda, de cursar o ensino médio em entidade de ensino privada mediante custeio pelo poder público (SARLET, 2015, p. 289).

O direito subjetivo ao ensino superior, contudo, é de controverso reconhecimento por parte da doutrina e jurisprudência ${ }^{8}$. O artigo 26 da DUDH consigna que o acesso ao ensino superior é baseado no mérito, já demonstrando que se aceitam limites de acesso ao ensino superior. Na mesma linha, a Constituição de 1988 determina que o acesso aos níveis mais elevados do ensino é subordinado à capacidade de cada pessoa ${ }^{9}$.

Outra questão fundamental é o direito à qualidade de ensino ${ }^{10}$. Segundo o inciso VII do artigo 206 da Constituição, o ensino será ministrado com base na garantia de padrão de

\footnotetext{
7 A Lei de diretrizes e bases da educação nacional (BRASIL, 1996) determina, em seu art. $4^{\circ}$, inciso I, a garantia de "educação básica obrigatória e gratuita dos 4 (quatro) aos 17 (dezessete) anos de idade, organizada da seguinte forma: a) pré-escola; b) ensino fundamental; c) ensino médio; [...]”, levando a crer que 17 anos seria uma idade desejável para que o estudante brasileiro concluísse o ensino médio.

${ }^{8}$ Analisando a doutrina alemã, Ingo Sarlet explica os limites do direito de acesso ao ensino superior (2015, p. 291): "A doutrina majoritária, em que pese a argumentação referida, optou por posicionar-se contrariamente a um direito originário a prestações, limitando-se a acolher um direito fundamental derivado (e, portanto, relativo), consistente na garantia de igual acesso ao ensino superior, na medida das instituições e vagas existentes. De qualquer modo, para além do reconhecimento de um direito derivado a prestações, houve quem atribuísse manifesto efeito didático à decisão do Tribunal Federal Constitucional nesta seara, uma vez que resultou em medidas concretas objetivando a ampliação das capacidades existentes na esfera do ensino superior, além de atuar - numa dimensão jurídico objetiva - como apelo às instâncias políticas para atuarem concretamente na realização do direito ao ensino superior."

${ }^{9}$ A redação do inciso V do art. 208 nada mais é que a reprodução do art. 74, item 3, alínea "d", da Constituição Portuguesa de 1976. Cita-se(PORTUGAL, p. 18): "3. Na realização da política de ensino incumbe ao Estado: [...] d) Garantir a todos os cidadãos, segundo as suas capacidades, o acesso aos graus mais elevados do ensino, da investigação científica e da criação artística [...]."

${ }^{10}$ Marcelo Gasque Furtado explica a questão da universalização (2009, p. 168): "Vivemos um período histórico em que o ensino fundamental, encontra-se, salvo exceções, praticamente universalizado no país, de forma que o caminho da superação do problema do acesso a vagas no sistema educacional começou a abrir uma nova senda de preocupações para o direito à educação. Segundo Oliveira (1996, p. 61) 'a questão da qualidade, ou temática da qualidade, substitui a temática mais tradicional da igualdade e da igualdade de oportunidades, e nessa perspectiva ela
}

Revista de Direito Brasileira | São Paulo, SP | v. 19 | n. 8 | p. 84 - 106 |Jan./Abr. 2018 
qualidade. Adicionalmente, a ideia de qualidade na educação ainda é mencionada no texto constitucional nos arts. 209, II; 211, $\S 1^{\text {o }} ; 214$, III e no art. 60, VI e $\S 1^{\text {o }}$ do Ato das Disposições Constitucionais Transitórias (FURTADO, 2009, p. 178) - reformulados pela Emenda Constitucional 53/06 ${ }^{11}$.

A Constituição Brasileira de 1988 inovou ao adicionar o tema da qualidade do ensino ao seu texto, não havendo antecedentes na história constitucional brasileira. Em verdade, a preocupação com a questão da qualidade na área de educação faz parte de desdobramentos históricos ocorridos, em especial, nas décadas finais do século XX e com repercussões sociais, econômicas e políticas em escala mundial (FURTADO, 2009, p. 175).

A Constituição, no entanto, não apresenta qualquer definição de qualidade do ensino (FURTADO, 2009, p. 177), somente assegurando a garantia de "padrão de qualidade" como um princípio constitucional. O preceito do art. 206, VII, determina a busca pela obtenção de qualidade do ensino. Resta refletir sobre quais seriam as condições e elementos que contribuiriam para a materialização dessa finalidade.

Ferreira Filho (1999, p. 244)demonstra certa desconfiança sobre a exequibilidade da qualidade de ensino: “A busca da qualidade do ensino é, sem dúvida, um princípio louvável. Garanti-la, porém, é uma promessa nem sempre executável”. José Afonso da Silva, por sua vez, procura identificar elementos objetivos do padrão de qualidade:

O padrão de qualidade do ensino depende de fatores intrínsecos e de fatores extrínsecos. Os primeiros estão vinculados à organização dos estabelecimentos escolares, que hão de estar aparelhados com o instrumental adequado a cada tipo de habilitação que oferecem, desde o preparo da criança para as sucessivas etapas do ensino até sua formação profissional - o que envolve a boa formação dos profissionais do ensino em cada uma dessas etapas, mas também requer a permanente atenção dos poderes públicos para com as condições materiais das escolas, tais como as tecnologias modernas de ensino, como a informatização dos estabelecimentos de ensino. Os segundos significam oferecer condições econômicas adequadas às famílias para que seus filhos tenham condições de auferir um bom aprendizado, porque o padrão de qualidade do ensino só se afere no rendimento escolar dos estudantes, e isso não depende apenas da boa qualidade dos professores, mas também, e principalmente, da predisposição do

funda um novo centro para a elaboração de políticas educacionais'. É certo que a falta de vagas continua sendo um problema sério no país, principalmente na etapa da educação infantil na modalidade creche, mas parece que cada vez mais o direito à educação vai se ampliando para abarcar preocupações que vão além da mera obtenção de matrícula para incluir o padrão de qualidade das vagas oferecidas. Se todos os setores da sociedade concordam com a ideia de que a educação deve ter qualidade, uma noção mais precisa do que seria essa qualidade do ensino parece perdida em uma cacofonia dentro da qual as vozes do debate destoam e tecem suas próprias concepções de qualidade no setor."

${ }^{11}$ Determina a Constituição Federal(BRASIL, 1988): "Art. 209. O ensino é livre à iniciativa privada, atendidas as

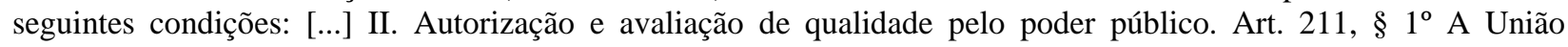
organizará o sistema federal de ensino e o dos territórios, financiará as instituições de ensino públicas federais e exercerá, em matéria educacional, função redistributiva e supletiva, de forma a garantir equalização de oportunidades educacionais e padrão mínimo de qualidade do ensino mediante assistência técnica e financeira aos estados, ao Distrito Federal e aos municípios. Art. 214. A lei estabelecerá o plano nacional de educação, de duração plurianual, visando à articulação e ao desenvolvimento do ensino em seus diversos níveis e à integração das ações do poder público que conduzam à: [...] III. Melhoria da qualidade do ensino. Art. 60 (ADCT). Até o 14º (décimo quarto) ano a partir da promulgação desta Emenda Constitucional, os estados, o Distrito Federal e os municípios destinarão parte dos recursos a que se refere o caput do art. 212 da Constituição Federal à manutenção e desenvolvimento da educação básica e à remuneração condigna dos trabalhadores da educação, respeitadas as seguintes disposições [...] VI. até $10 \%$ (dez por cento) da complementação da União prevista no inciso V do caput deste artigo poderá ser distribuída para os Fundos por meio de programas direcionados para a melhoria da qualidade da educação, na forma da lei a que se refere o inciso III do caput deste artigo. [...] $\S 1^{\circ}$ A União, os estados, o Distrito Federal e os municípios deverão assegurar, no financiamento da educação básica, a melhoria da qualidade de ensino, de forma a garantir padrão mínimo definido nacionalmente."

Revista de Direito Brasileira | São Paulo, SP | v. 19 | n. 8 | p. 84- 106 |Jan./Abr. 2018 
alunado para o aprendizado - o que, na mais das vezes, depende de uma boa alimentação e da posse de material escolar apropriado(SILVA, 2006, p. 789).

Furtado (2009, p. 177) sintetizando o pensamento de outros juristas acerca do art. 206, VII da CF, afirma que o padrão de qualidade do ensino seria atingido por uma série complexa de meios que envolveria:

[...] condições materiais para o ensino, tanto das instituições de ensino (existência em número suficiente, boas condições do edifício escolar, do equipamento físico disponível, limpeza e manutenção efetivos, fornecimento regular de água, energia elétrica etc.) como dos alunos (fornecimento de material escolar, merenda, transporte etc.); condições dos recursos humanos ligados ao ensino (formação adequada, atualização constante, remuneração condigna etc.); condições de natureza pedagógica (currículos adequados, metodologias apropriadas ao perfil do alunado etc.) resultados cognitivos do processo de aprendizagem aferíveis por meio de avaliações etc.(FURTADO, 2009, p. 177).

Além do mais, é preciso ressaltar que a obrigação constitucional geral da família, da sociedade e do Estado com a educação não é somente prevista no art. 205. Tal obrigação foi reiterada em outros artigos da Constituição (BRASIL, 1988). A repetição ocorreu no art. 227, caput e $\S 3^{\circ}$, incs. I e III, (proteção especial por parte da criança e do adolescente); e art. 229 (dever dos pais de criarem e educarem os filhos menores). Nota-se que, ao lado do Estado, o envolvimento da família e sociedade é essencial para a obtenção do ensino público universal de qualidade.

Portanto, o Estado Social Democrático de Direitopossui o dever de garantir a todos o acesso ao conhecimento, com o escopo de tutelar a liberdade pública. Adicionalmente, o Poder Público deve fornecer educação gratuita e universal, visto que esse possui a incumbência constitucional de garantir a todos uma existência digna e em conformidade com a justiça social. Por fim, nota-se que a educação gratuita e universal, por si só, é insuficiente enquanto política pública social - devendo atingir padrões de qualidade satisfatórios para todos os alunos da rede pública.

\section{A ORDEM ECONÔMICA CONSTITUCIONAL SOB O ASPECTO DA EXTRAFISCALIDADE E DO DESENVOLVIMENTO SUSTENTÁVEL}

A extrafiscalidade consiste no emprego de instrumentos que, embora tenham natureza tributária, não são voltados primordialmente para a obtenção de receitas, mas sim para a obtenção dedeterminados comportamentos e resultados econômicos ou sociais ${ }^{12}$. É primordial que tais instrumentos tenham o escopo de realizar valores constitucionalmente contemplados no Estado de Direito (COSTA, 2014, p. 48) - não podendo ser utilizados sem critérios técnicos nem estudos socioeconômicos específicos ${ }^{13}$.

\footnotetext{
${ }^{12}$ Denota-se o conceito delineado por José Casalta Nabais(1998, p. 629): “A extrafiscalidade traduz-se no conjunto de normas que, embora formalmente integrem o direito fiscal, tem por finalidade principal ou dominante a consecução de determinados resultados económicos ou sociais através da utilização do instrumento fiscal e não a obtenção de receitas para fazer face às despesas públicas. Trata-se assim de normas (fiscais) que, ao preverem uma tributação, isto é, uma ablação ou amputação pecuniária (impostos), ou uma não tributação ou uma tributação menor à requerida pelo critério da capacidade contributiva, isto é, uma renúncia total ou parcial a essa ablação ou amputação (benefícios fiscais), estão dominadas pelo intuito de actuardirectamente sobre os comportamentos económicos e sociais dos seus destinatários, desincentivando-os, neutralizando-os nos seus efeitos económicos e sociais ou fomentando-os, ou seja, de normas que contêm medidas de política económica e social”.

${ }^{13}$ YarivBrauner (2013, p. 54-55), ao analisar os incentivos fiscais usualmente utilizados em países em desenvolvimento, alerta sobre seu uso indiscriminado: "Taxincentives in their usual Revista de Direito Brasileira | São Paulo, SP | v. 19 | n. 8 | p. 84 - 106 |Jan./Abr. 2018
} 
A extrafiscalidade como instrumento estatal de consecução de comportamentos desejáveis no setor privado é indiscutível ${ }^{14}$. A intervenção do Estado na iniciativa privada é consequência lógica do Estado Social Democrático de Direito adotado na Constituição Republicana de 1988.

A ordem econômica brasileira, conforme art. 170 da Constituição (BRASIL, 1988), funda-se na valorização do trabalho humano e na livre iniciativa, tendo por escopo a garantia de existência digna a todos e da obtenção da justiça social. A ordem econômica deve seguir ainda o rol de princípios expressos no referido artigo, sendo eles: soberania nacional; propriedade privada; função social da propriedade; livre concorrência; defesa do consumidor; defesa do meio ambiente; redução das desigualdades regionais e sociais; busca do pleno emprego; e tratamento favorecido para as empresas de pequeno porte constituídas sob as leis brasileiras e que tenham sua sede e administração no país.

Linda-se que o art. 170 da Constituição (BRASIL, 1988) lança as bases do desenvolvimento sustentável, sendo esse estruturado em diversas áreas. O $\S 1^{\circ}$ do art. 174 do texto constitucional, no mesmo sentido, declara o dever de o Governo Federal legislar sobre as diretrizes e bases do "planejamento do desenvolvimento nacional equilibrado", compatibilizando planos nacionais e regionais de desenvolvimento.

Tais noções são compatíveis com o conceito ditado pela Comissão Mundial sobre Meio Ambiente e Desenvolvimento(1988, p. 46), no sentido de que o desenvolvimento sustentável é o "que procura satisfazer as necessidades da geração atual, sem comprometer a capacidade das gerações futuras de satisfazerem as suas próprias necessidades".

Enquanto instrumento para consecução dos preceitos do art. 170 da Constituição Federal, a política extrafiscal possui o escopo de modelar comportamentos econômicos ou sociais dos agentes privados ${ }^{15}$. Machado $(2005$, p. 30) entende que os tributos podem ser classificados conforme três funções específicas: fiscal, correspondendo essencialmente à arrecadação de recursos financeiros para o Estado; extrafiscal, apresentando uma interferência estatal no domínio econômico; e parafiscal, quando o Estado arrecada recursos para atividades que, embora não sejam suas funções próprias, desenvolvem-se por meio de entidades específicas.

formatcannotgenerallyassistdeveloping countries in theirquest for development. Moreover, they are not truly used by developing countries with development in mind, but rather as a shield to alleviate the harm of tax competition. An obvious consequence of this observation is that developing countries should, if possible, refrain from using such tax incentives, unless they are in a position to specifically identify their goals and tailor them for their needs, based on rigid and independent research, and are able to fine-tune them and monitor their effect (and success or failure) over time".

14 “A par das variadas finalidades pelas quais a extrafiscalidade tradicionalmente é aplicada, e sendo o tributo um instrumento de natureza financeira, interferindo no patrimônio, na atividade econômica, na vida social, cultural, político e ambiental, torna-se hábil instrumento para a modelagem de comportamentos humanos. A lógica é bastante simples. Tributa-se mais a atividade que se pretenda desincentivar. Ao contrário, tributa-se menos a atividade que se pretenda incentivar. Com esse simples mecanismo, o Estado descobriu, ou reconheceu, uma ferramenta quase ideal, e até melhor que outras medidas coercitivas como as penas restritivas de liberdade ou de direitos (afinal, é quase uma verdade universal que não há lugar melhor para atingir o cidadão do que algo que ele sinta no próprio bolso)(...).” (MARTINS; TEODOROVICZ, 2010, p. 173).

${ }^{15} \mathrm{O}$ professor José Casalta Nabais (2007, p. 366)leciona sobre as diferenças essenciais entre políticas fiscal e extrafiscal: "Dissemos que a política fiscal se traduz na instituição, organização e cobrança de impostos. Pelo que o qualificativo «fiscal» que acompanha a palavra «política» se reporta exclusivamente ao facto de a mesma se traduzir em impostos, nada nos dizendo sobre o objectivo ou objectivos prosseguidos através desse instrumento. Mas, como também referimos, esse instrumento, embora tenha como objectivo primordial, como não pode deixar de ser, a obtenção de receitas, excepcionalmente pode ter por objectivo a modelação de comportamentos económicos ou sociais. Assim, se no primeiro caso, a política é fiscal tanto pelo instrumento utilizado quanto pelo objectivo prosseguido, já no segundo, embora seja fiscal pelo instrumento em que se concretiza, revela-se extrafiscal pelos objectivos que serve. Daí que se imponham algumas palavras a respeito da utilização dos impostos com finalidades extrafiscais. Por outras palavras, há que mencionar alguns aspectos que se prendem com o fenómeno e a problemática da extrafiscalidade. Mais especificamente, vamos aludir à dimensão e às vias pelas quais opera esse fenómeno, bem como à inserção deste no direito dos impostos".

Revista de Direito Brasileira | São Paulo, SP | v. 19 | n. 8 | p. 84- 106 |Jan./Abr. 2018 
Para o escopo do presente trabalho, o interesse é o exame da finalidade extrafiscal dos tributos, pois é nesse campo que se constrói a teoria dos incentivos fiscais que é apresentada no campo do ensino escolar público.

Nabais (2007, p. 368) denota que a extrafiscalidade integra o direito econômico e não o direito fiscal, motivo pelo qual não segue os rígidos limites constitucionais do direito tributário. A extrafiscalidade seria dominada por ideias de flexibilidade e seleção ${ }^{16}$.Gouvêa, por outro lado, delineia o conceito de extrafiscalidade da seguinte forma:

A extrafiscalidade se constitui no 'algo a mais' que a obtenção de receitas tributárias; liga-se a valores constitucionais; pode ser representada por isenções, benefícios fiscais, progressividade de alíquotas, finalidades especiais, entre outras formas que assume, criando diferenças entre os indivíduos, que são, em última análise, agentes políticos, econômicos e sociais [...](GOUVÊA,2006, p. $3)$.

A extrafiscalidade - agregada à fiscalidade - atua finalisticamente e apresenta uma dimensão distinta do Direito Tributário enquanto instrumento de transformação social capaz de realizar os valores e fins constitucionais (RODRIGUES; DA SILVA MULLER, 2012, p. 26-49).

Na seara da extrafiscalidade voltada para o desenvolvimento sustentável, Gouvêa (2006, p. 13) destaca a estreita relação entre os tributos com finalidades extrafiscais e o Estado regulador. Linda-se, ainda, a intrínseca relação entre o meio ambiente equilibrado e a arrecadação tributária. O erário consubstancia fonte de financiamento de parte dos custos da recuperação e proteção do meio ambiente degradado pela atividade econômica privada. Se não houver sustentabilidade econômica, certamente não haverá espaço para sustentabilidade ambiental ${ }^{17}$.

A extrafiscalidade opera de duas maneiras: impostos ou agravamentos extrafiscais de impostos e os benefícios físcais. A técnica mais utilizada da extrafiscalidade é a dos benefícios fiscais - especialmente os incentivos fiscais, dado o seu caráter dinâmico. Tal realidade extrafiscal coaduna-se com o próprio entendimento atual do direito que, no dizer de Norberto Bobbio(apud NABAIS, 2007, p. 367), tem hoje uma cada vez mais uma função promocional.

Na seara da extrafiscalidade, podem-se destacar, dentre vários, os seguintes instrumentos (ELALI, 2007, p. 114): a) subvenções diretas; b) subsídios; c) incentivos fiscais; d) incentivos financeiros e creditícios; e) empréstimos bonificados; f) garantias; e g) incentivos tributários (imunidades, isenções, diferimentos, reduções de alíquotas e base de cálculo, anistias, remissões e regimes especiais de tributação).

Por óbvio, as políticas extrafiscais devem obedecer ao pacto federativo. Isso implica que os incentivos fiscais devem observar as competências tributárias da União, Estados, Distrito Federal e dos Municípios (arts. 153, 155 e 156 da Constituição Federal). Somente podem

\footnotetext{
${ }^{16}$ Flexibilidade e seleção não são irrestritas. Segundo o art. 150, § 6 , da CF: "qualquer subsídio ou isenção, redução de base de cálculo, concessão de crédito presumido, anistia ou remissão, relativos a impostos, taxas ou contribuições, só poderá ser concedido mediante lei específica, federal, estadual ou municipal, que regule exclusivamente as matérias acima enumeradas ou o correspondente tributo ou contribuição, sem prejuízo do disposto no art. $155, \S 22^{\circ}$, XII, g".

${ }^{17}$ Nesse sentido, José Casalta Nabais (2007, p. 369) explica a clara interdependência entre economia de um país e a sustentabilidade ambiental: "Pois bem, a exigência de um desenvolvimento económico e social sustentável não pode ser, pela própria natureza das coisas, igual para todos os países, dependendo a mesma, como bem se compreende, do grau de desenvolvimento que estes tenham atingido. Pois antes da sustentabilidade ambiental está, obviamente, a sustentabilidade económica, pelo menos enquanto esta não tiver alcançado um patamar correspondente ao dos países ditos desenvolvidos. Com efeito, é preciso ter presente que primum viveredeinde planeta salvare, uma vez que se um país for colocado em risco de sobrevivência, tornando-se inviável, por falta de sustentabilidade econômica, deixa de ter sentido falar na sua sustentabilidade ecológica. Ou, noutros termos, os países em vias de desenvolvimento não podem ser condenados a permanecer nesse estado a pretexto de que é preciso salvar o planeta".
} 
conceder isenções específicas os entes políticos que possuem a competência constitucional específica para tributar na área.

Embora a extrafiscalidade tenha que respeitar normas constitucionais e legais, tal instituto encontra-se dominado por ideias de flexibilidade e seleção. Não segue, portanto, os rígidos limites constitucionais próprios do direito fiscal (NABAIS, 2007, p. 368). O gestor público goza de determinada discricionariedade na elaboração de políticas extrafiscais.

Destaca-se que os incentivos extrafiscais podem ser classificados conforme o âmbito de atuação - sobre a receita ou sobre a despesa pública (artigo 165 da Constituição Federal). Há no campo da receita: a isenção, o diferimento, a remissão e a anistia. No tocante à despesa, ressaltam-se: a subvenção, o crédito presumido e os subsídios.

Em regra, os incentivos sobre as despesas públicas seriam os que permitem um controle orçamentário mais eficaz, devido às suas características principais. Por outro lado, os benefícios sobre a receita, ou as desonerações fiscais, são considerados os benefícios propriamente ditos (PIRES, 2007, p. 34).

\section{EXTRAFISCALIDADE, ENSINO DE QUALIDADE E DESENVOLVIMENTO}

Dados educacionais indicam que o acesso à educação no ensino escolar público, embora expandido nas últimas décadas (FURTADO, 2009, p. 167), ainda atinge níveis insatisfatórios ${ }^{18}$. Além disso, há uma variação muito grande nas avaliações de qualidade de ensino público escolar quando se faz uma pesquisa comparativa nos âmbitos regional ${ }^{19}$ e local.

Vários fatores contribuem para o trabalho de envidar mais esforços no financiamento e desenvolvimento dos ensinos escolares básico, fundamental e médio, prescindindo do ensino superior $^{20}$. Ressaltam-se alguns deles: a) controvérsia doutrinária e jurisprudencial acerca da

\footnotetext{
${ }^{18}$ Segundo dados do INEP em 2016, banheiros adequados aos alunos com deficiência ou mobilidade reduzida estão disponíveis em apenas 58,0\% das escolas de ensino médio. Em relação à adequação das vias e dependências para o mesmo público, o percentual é de 46,7\%. Em relação às escolas de ensino fundamental, tais porcentagens descem para $8,0 \%$ e $38,7 \%$, respectivamente.

${ }^{19}$ De acordo com dados coletados pelo INEP durante o ano de 2016, a taxa de reprovação do ensino médio do sistema público no Centro-Oeste foi de $6,8 \%$ dos alunos, enquanto a mesma taxa na região Norte foi $10,1 \%$. No tocante à taxa de abandono, as mesmas regiões tiveram os percentuais de 6,8\% e 10,8\%, respectivamente.

${ }^{20}$ Sobre a situação atual do sistema de ensino superior brasileiro (DIAS; LEITÃO; FREITAS, 2017, P. 17):“A estrutura do Estado paternalista brasileiro, pautada em programas assistenciais de transferência de renda e em um distorcido modelo de educação que privilegia o ensino superior em detrimento da educação básica, não promove a inclusão social. A redistribuição de renda deve ser uma política permanente de Estado, mas não deve significar suporte pecuniário permanente para hipossuficientes. A simplória e limitada ação estatal de extrair capital da população produtiva e distribuir (ou seja, redistribuir) para os que se dizem vulneráveis, absolutamente, não é um mecanismo de geração de riqueza. Ao contrário, a pretexto de incluir segmentos marginalizados, o Estado promove a exclusão social, pois fortalece uma relação patológica de dependência socioeconômica que estimula a desocupação e o trabalho informal. É fundamental que o Estado formate políticas públicas capazes de gerar riqueza, e não simplesmente redistribuí-la. No campo da educação, nos últimos anos, o Governo passou a investir bilhões de reais em programas de acesso ao ensino superior. Afinal, qual foi o impacto social da medida? A taxa de desemprego diminuiu? Ao contrário. Praticamente dobrou. Enquanto isso, parcela considerável da população brasileira é composta por analfabetos (absolutos ou funcionais). Não é no nível superior em que ocorrem as reais transformações sociais de que o Brasil tanto necessita. É na educação básica. Além do mais, o progressivo investimento em programas sociais e educacionais não inclusivos, paradoxalmente, contribui para a redução da qualidade de vida de vários brasileiros que, direta ou indiretamente, lastreiam as generosas ações estatais através de uma tributação que beira a ideia de confisco. O governo alcança resultados rasos, pois não implementa apoio no desenvolvimento socioeconômico dos favorecidos. Ao não lhes abrir a porta para as oportunidades, fideliza o ciclo da pobreza. Sob outro viés, ao lhes abrir a porta para o ensino superior, afiança a ilusão de que o diploma universitário resolverá o problema do desemprego. Não resolverá. Num país em que parcela considerável da população universitária é composta por analfabetos funcionais, um diploma de graduação não certifica qualificação, muito menos competência”.
}

Revista de Direito Brasileira | São Paulo, SP | v. 19 | n. 8 | p. 84- 106 |Jan./Abr. 2018 
existência de um direito público subjetivo e universal ao ensino superior; b) o fato de o ensino superior somente alcançar a excelência se precedido de uma educação básica e fundamental de qualidade; e c) o caráter inclusivo do ensino básico e fundamental, permitindo que a população carente disponha de meios para exercer a sua cidadania e adquirir emprego, bens e serviços.

O presente estudo limita-se a avaliar apenas a concessão de incentivos físcais que tenham escopo a melhoria do ensino público escolar e a forma que o Estado pode utilizar dessa sua prerrogativa para induzir investimentos na área de educação ${ }^{21}$. Deste modo, não se foca aqui na especificação exaustiva de toda e qualquer espécie de incentivo e seus potenciais usos em prol do meio educacional. Atém-se, no caso, à relevância constitucional de uma nova fonte de investimento na educação, expondo algumas reflexões e poucas proposições legislativas.

A extrafiscalidade em prol da educação busca seu fundamento no art. 170 da Constituição Federal (BRASIL, 1988). A ordem econômica, fundada na valorização do trabalho humano e na livre iniciativa, objetiva a concreção da dignidade da pessoa humana e da justiça social. Legitima-se a intervenção do Estado na economia, logo, para assegurar o direito indisponível à educação de qualidade, incentivando a colaboração da sociedade para a obtenção do pleno desenvolvimento da pessoa cidadã e qualificada para o mercado de trabalho (art. 205 da Constituição).

Um estudo exaustivo da extrafiscalidade (o que não é o escopo desse artigo) não pode se limitar à seara do Direito - linda-se uma necessária análise transdisciplinar com a economia, sociologia e educação. No campo da economia, por exemplo, o investimento na educação do indivíduo possui suas bases na teoria do capital humano desenvolvida por Theodore Schultz (1987). O economista entendia que a educação tornava as pessoas mais produtivas, acarretando o desenvolvimento socioeconômico do país. Entendia ainda que a boa atenção à saúde aumentava o retorno do investimento em educação. Dentro da ideia de capital humano, introduziu a ideia de "capital educacional", relacionando-o, especificamente, aos investimentos na área de educação (1987, p. 112). Schultz (1987, p. 113) acreditava que um bom ensino escolar proporciona futuros serviços em prol da sociedade. Esses serviços resultam em futuras rendas, futura capacidade de autoemprego, valorização de atividades familiares e futuras satisfações de serviço. Ressalta também uma futura aptidão empreendedora daqueles que possuem educação de qualidade. Por fim, declarava que um ensino escolar de qualidade dava subsídios para o desenvolvimento econômico dos países subdesenvolvidos ${ }^{22}$.

Nota-se uma relação intrínseca da educação com o desenvolvimento sustentável. Nessa linha de raciocínio, a ONU elaborou, em 2015, a agenda 2030 de desenvolvimento sustentável (A AGENDA 2030 PARA O DESENVOLVIMENTO SUSTENTÁVEL, 2015) - um documento contendo 17 objetivos para obtenção do desenvolvimento sustentável. O $4^{\circ}$ objetivo desta lista é: "Assegurar a educação inclusiva e equitativa e de qualidade, e promover oportunidades de aprendizagem ao longo da vida para todos ${ }^{23}$ ". A educação, enquanto fator de desenvolvimento

\footnotetext{
${ }^{21}$ Embora pouco explorada, a extrafiscalidade como forma de incentivo à educação não é novidade no cenário nacional. A Lei $\mathrm{n}^{\circ}$ 11.096/05, que institui e regula o Programa Universidade para Todos (PROUNI), prevê, em seu art. $8^{\circ}$, isenções de diversos tributos federais para as instituições de ensino superior que aderirem ao programa.

${ }^{22}$ Em sua obra "investindo no povo", Schultz (1987, p. 112)relatou a rápida recuperação da Alemanha e do Japão pós-segunda guerra mundial, comparando a situação desses países a do Reino Unido, onde ainda havia racionamento de alimentos muito tempo depois da guerra. Chegou-se à conclusão de que a superior velocidade de recuperação era fruto de uma população saudável e altamente educada. Segundo o autor, "nenhum indivíduo pode vender o seu capital educacional. Nem tampouco lhe é possível transferir o volume de instrução que possui, como presente, para outra pessoa. É este volume de capital humano, para usar e conservar enquanto viver".

${ }^{23}$ Cita-se a íntegra do objetivo $4^{\circ}$ e suas metas (ASSEMBLEIA GERAL DAS NAÇÕES UNIDAS, 2015, p. 23-24): "Objetivo 4. Assegurar a educação inclusiva e equitativa e de qualidade, e promover oportunidades de aprendizagem ao longo da vida para todos. 4.1 Até 2030, garantir que todas as meninas e meninos completem o ensino primário e secundário livre, equitativo e de qualidade, que conduza a resultados de aprendizagem relevantes e eficazes. 4.2 Até 2030, garantir que todos as meninas e meninos tenham acesso a um desenvolvimento de qualidade na primeira infância, cuidados e educação pré-escolar, de modo que eles estejam prontos para o ensino primário. 4.3 Até 2030,

Revista de Direito Brasileira | São Paulo, SP | v. 19 | n. 8 | p. 84 - 106 |Jan./Abr. 2018
} 
sustentável, compatibiliza-se com os preceitos constitucionais da ordem econômica (art. 170 e seguintes da $\mathrm{CF}$ ); e, no plano internacional, com os objetivos de desenvolvimento sustentável da ONU.

A relação entre educação e desenvolvimento possui vários desdobramentos. Um desses desdobramentos é a segurança pública. Compreendendo que a educação é um forte instrumento contra a violência em qualquer de suas formas, o art. 26 da Declaração Universal de Direitos Humanos de 1948(ASSEMBLEIA GERAL DA ONU, 1948, p. 14)determina que a educação deve ser orientada no sentido de fortalecer o "respeito pelos direitos humanos e pelas liberdades fundamentais". Seguindo a mesma linha de raciocínio, a norma prevê que a educação "promoverá a compreensão, a tolerância e a amizade entre todas as nações e grupos raciais ou religiosos, e coadjuvará as atividades das Nações Unidas em prol da manutenção da paz". A educação não é vista apenas como um direito humano, mas também como um instrumento de efetivação de outros direitos humanos ${ }^{24}$.

Estudos na área de economia têm ressaltado a educação como fator determinante para os índices de criminalidade. A instrução do indivíduo influencia o crime de quatro formas: a) a educação aumenta os salários futuros, elevando os custos de oportunidade do crime, visto que a prática do ilícito torna-se inviável; b) a educação pode atingir diretamente os retornos financeiros ou psíquicos do crime; c) a educação pode alterar preferências diante do risco, pois quanto maior a escolaridade de um indivíduo, mais elevada é sua aversão ao risco, desencorajando o ato criminoso; d) a educação pode afetar redes sociais ou grupos de indivíduos, porquantojovens que desistem da escola podem ser influenciados negativamente por grupos criminosos(TEIXEIRA, 2011, p. 23-24).

assegurar a igualdade de acesso para todos os homens e mulheres à educação técnica, profissional e superior de qualidade, a preços acessíveis, incluindo universidade. 4.4 Até 2030, aumentar substancialmente o número de jovens e adultos que tenham habilidades relevantes, inclusive competências técnicas e profissionais, para emprego, trabalho decente e empreendedorismo. 4.5 Até 2030, eliminar as disparidades de gênero na educação e garantir a igualdade de acesso a todos os níveis de educação e formação profissional para os mais vulneráveis, incluindo as pessoas com deficiência, povos indígenas e as crianças em situação de vulnerabilidade. 4.6 Até 2030, garantir que todos os jovens e uma substancial proporção dos adultos, homens e mulheres estejam alfabetizados e tenham adquirido o conhecimento básico de matemática 4.7 Até 2030, garantir que todos os alunos adquiram conhecimentos e habilidades necessárias para promover o desenvolvimento sustentável, inclusive, entre outros, por meio da educação para o desenvolvimento sustentável e estilos de vida sustentáveis, direitos humanos, igualdade de gênero, promoção de uma cultura de paz e não violência, cidadania global e valorização da diversidade cultural e da contribuição da cultura para o desenvolvimento sustentável. 4.a Construir e melhorar instalações físicas para educação, apropriadas para crianças e sensíveis às deficiências e ao gênero, e que proporcionem ambientes de aprendizagem seguros e não violentos, inclusivos e eficazes para todos. 4.b Até 2020, substancialmente ampliar globalmente o número de bolsas de estudo para os países em desenvolvimento, em particular os países menos desenvolvidos, pequenos Estados insulares em desenvolvimento e os países africanos, para o ensino superior, incluindo programas de formação profissional, de tecnologia da informação e da comunicação, técnicos, de engenharia e programas científicos em países desenvolvidos e outros países em desenvolvimento. 4.c Até 2030, substancialmente aumentar o contingente de professores qualificados, inclusive por meio da cooperação internacional para a formação de professores, nos países em desenvolvimento, especialmente os países menos desenvolvidos e pequenos Estados insulares em desenvolvimento".

${ }^{24}$ Sobre a educação como instrumento necessário para efetivação dos direitos humanos: "O homem é um ser em construção que pode ser melhorado. Sua existência é resultado dessa busca de aperfeiçoamento e da sua capacidade de superar os instintos egoístas e nocivos à vida em sociedade. Por isso, é possível defender e promover a dignidade do indivíduo mediante meios educativos apropriados, como é o caso de uma educação voltada para os direitos humanos. Esta deve, pois, preparar o sujeito para o exercício da cidadania e, sobretudo, para o reconhecimento da dignidade que define sua natureza e condição. O processo educacional pode fornecer ao homem os instrumentos necessários para que ele possa constituir as bases de um viver compartilhado e baseado nos valores de solidariedade, justiça, respeito mútuo, liberdade e responsabilidade. A realização desses valores o torna mais apto a viver com dignidade. Porém, sem eles o homem se revela destituído de sua essênciafundamental, ou seja, ele perde aquilo que define o seu ser: a sua humanidade. A educação em direitos humanos é, pois, uma forma de o sujeito reconhecer a importância da dignidade e, sobretudo, agir visando a conquista, apreservação e a promoção de uma vida digna" (PEQUENO, 2016, p. 30). 
Um trabalho elucidativo sobre o tema foi feito por Evandro Camargos Teixeira. Tal economista analisou o impacto da taxa de abandono escolar dos alunos da primeira série do ensino médio, defasada em um período, sobre a taxa de homicídios nos estados brasileiros entre os anos de 2001 e 2005. Sua conclusão foi a seguinte:

Durante toda a exposição do trabalho é visível que educação e criminalidade possuem uma importante relação intrínseca. [...]. Além disso, a variável de educação - a taxa de abandono escolar dos alunos da primeira série do ensino médio - é defasada em um período. Nesse sentido, o estudo permite a análise do impacto do abandono escolar de um adolescente em um período e seu impacto na criminalidade do período seguinte. Tal aspecto é muito relevante, pois sabese que existe uma certa defasagem entre o período em que o adolescente abandona a escola e o momento em que ele decide ingressar em uma atividade ilícita. Assim, ao analisar os resultados, verificou-se que existe uma relação diretamente proporcional e estatisticamente significativa entre a taxa de abandono escolar defasada em um período e as taxas de homicídios nos estados no período em questão. A partir desse resultado pode-se inferir que um ano após abandonar a escola, no início do ensino médio, o jovem apresenta uma maior probabilidade de cometer crimes. Nesse período de um ano, ele pode ter se defrontado com diversas dificuldades: baixos salários no mercado de trabalho formal, elevadas taxas de desemprego, ou ainda pode ter sido influenciado negativamente por gangues. Todos estes aspectos incentivam a entrada do jovem no 'mundo do crime'. (TEIXEIRA, 2011, p. 50-51)

A qualidade de ensino também é uma questão fundamental para a manutenção do aluno no colégio e longe do crime. Tal questão influencia o aluno e sua família, podendo estimulá-los a investir na educaçãoou não ${ }^{25}$.

A busca de meios alternativos de investimento na educação de qualidade objetiva trazer benefícios diretos para a área da educação e, consequentemente, indiretos para toda a sociedade. A educação comprovadamente influencia países nas áreas do desenvolvimento econômico, social e humano. Políticas fiscais e extrafiscais que busquem esse tipo de desenvolvimento são inevitavelmente legítimas perante a Constituição Federal.

\section{FEDERALISMO DE COOPERAÇÃO, EXTRAFISCALIDADE E ICMS EDUCACIONAL: INDUÇÃO DEINVESTIMENTO NO ENSINO PÚBLICO ESCOLARE PODER PÚBLICO MUNICIPAL}

No tocante ao dever de o Poder Público oferecer uma política de educação de qualidade, a Constituição (BRASIL, 1988) outorga competências materiais e legislativas de forma concorrente para os sistemas de ensino da União, dos Estados e dos Municípios (art. 211). Tal instituto constitucional é chamado de federalismo de cooperação - que consiste no dever constitucional de a União, Estados e Municípios atuarem conjuntamente para atingir os fins sociais do Estado Democrático de Direito ${ }^{26}$. Dentro de tal modelo, destacam-se os percentuais da

\footnotetext{
25 "Geralmente, os pais apoiam e investem quando percebem que o filho corresponde a tal investimento e caso a escola seja de boa qualidade. Nesse sentido, pode-se dizer que escolas de má qualidade diminuem o ímpeto dos alunos em estudar e dos pais em investir, pois ocorre uma diminuição na renda esperada futura a ser auferida pelos adolescentes" (TEIXEIRA, 2011, p. 52).

${ }^{26}$ Gilmar Mendes (2015, p. 666)explica o instituto chamado federalismo de cooperação: “A Constituição de 1988 adotou a sistemática preconizada pelo federalismo cooperativo, em que o Estado, permeado pelos compromissos de bem-estar social, deve buscar a isonomia material e atuação conjunta para erradicação das grandes desigualdades sociais e econômicas. Para tanto, foi dado destaque à distribuição de receitas pelo produto arrecadado e ampliada participação de Estados e Municípios na renda tributária. Além da previsão da criação de fundos públicos e do
}

Revista de Direito Brasileira | São Paulo, SP | v. 19 | n. 8 | p. 84 - 106 |Jan./Abr. 2018 
receita de impostos para aplicação na manutenção e desenvolvimento do ensino (arts. 22, XXIV, 24, VIII, 30, VI, 208 e 212), assim como o Fundo de Manutenção e Desenvolvimento da Educação Básica e de Valorização dos Profissionais da Educação - FUNDEB (art. 60 do ADCT).

Na medida em que tais receitas tributárias já são vinculadas ao custeio da educação, não serão elas objeto do presente trabalho. A extrafiscalidade como incentivo à educação tratada neste trabalho buscará fontes diversas de custeio.

Inicialmente, ressalta-se a importância do poder público municipal na gestão da educação de ensino fundamental. Nas últimas décadas, houve um crescimento exponencial do número de matrículas efetuadas nas redes municipais de ensino ${ }^{27}$. Considerando tal importância do município na gestão pública, são imprescindíveis para desenvolvimento da educação: a maior aproximação dos gestores públicos com os administrados(reduzindo as instâncias políticas); a interação entre a comunidade e os agentes públicos municipais; e a participação mais ativa das famílias na gestão do ensino público ${ }^{28}$.

Uma ferramenta importante para o custeio da educaçãoé o repasse legal de verbas de ICMS para o ensino público escolar, na forma do art. 158, parágrafo único, II, da Constituição Federal (BRASIL, 1988) ${ }^{29}$. A figura do "ICMS educacional" ou "ICMS educação" não é inédita na legislação do país.A educação aparece como critério para divisão do ICMS em estados como Ceará, Minas Gerais, Pernambuco e no Amapá.Nos casos de Minas Gerais ${ }^{30}$, Amapá $^{31}$ e

federalismo cooperativo como formas de combate aos desequilíbrios regionais, a Carta Constitucional também destaca o planejamento, favorecendo-se a execução de políticas públicas no longo prazo. É o que se depreende do parágrafo único do art. 23 da CF ('Lei complementar fixará normas para a cooperação entre a União e os Estados, o Distrito Federal e os Municípios, tendo em vista o equilíbrio do desenvolvimento e do bem-estar em âmbito nacional')."

${ }^{27}$ Destaca-se que tal mudança decorre também da instituição do Fundo de Manutenção e Desenvolvimento do Ensino Fundamental e de Valorização do Magistério (FUNDEF): "Ao observar-se o número de matrículas por esfera de governo no Brasil, percebe-se que as posições dos estados e dos municípios inverteram-se no período. Antes do Fundo os municípios respondiam por menos de $40 \%$ das matrículas e, em 2006, respondem por pouco mais de $60 \%$. Em todos os estados o percentual de matrículas municipais avançou, alcançando quase $77 \%$ no Nordeste - região com maior percentual de matrículas em rede municipal - e $46 \%$ no Centro-Oeste - região do país na qual a rede estadual é ainda mais presente. A taxa de escolarização líquida nos mostra que o país de fato avançou rumo à universalização desse nível de ensino, uma vez que a taxa nacional variou quase $10 \%$ no período - de $85,4 \%$ para $94,8 \%$. A região nordeste foi a que mais avançou, saindo de um patamar de $76,1 \%$ para $93,4 \%$ em 2006 ." (FRANZESE, 2010, p.110).

${ }^{28}$ Em 2015, o Ministério da Educação (MEC) divulgou o resultado do Exame Nacional do Ensino Médio e o ranking de escolas. Pelo resultado, a escola Augustinho Brandão, do município de Cocal Alves/PI, alcançou a média de 553,93 na prova objetiva, a maior do país entre as escolas de estudantes de baixa renda. A média a deixou com a quinta colocação entre todas as escolas públicas do estado do Piaú, sendo que as quatro primeiras são todas instituições públicas federais. Seu sucesso é fruto de esforços e conscientização da própria comunidade local em prol dos alunos. Fonte: <https://educacao.uol.com.br/noticias/2014/10/23/escola-pobre-do-piaui-tem-153-medalhas-dematematica-quer-saber-como.htm>. Acesso em: 06 out. 2017.

${ }^{29}$ No campo socioambiental, há a previsão do ICMS ecológico, que determina critérios ambientais que calculam o quanto cada município irá receber do produto da arrecadação do imposto estadual. No Mato Grosso do Sul, o ICMS ecológico é regulado pela Lei Complementar Estadual n. 57/1991.

${ }^{30}$ Lei estadual $n^{\circ}$ 18.030/2009 (MINAS GERAIS): “Art. $2^{\circ}$ Os valores decorrentes da aplicação dos percentuais relativos ao critério "educação", de que trata o inciso V do art. $1^{\circ}$, serão distribuídos aos Municípios de acordo com a relação entre o total de alunos atendidos, inclusive os alunos da pré-escola, e a capacidade mínima de atendimento do Município, relativamente aos dados do ano civil imediatamente anterior, calculada de acordo com o Anexo III desta Lei e publicada pela Fundação João Pinheiro até o dia 31 de agosto de cada ano, com base em dados fornecidos pela Secretaria de Estado de Educação e pelo Tribunal de Contas do Estado. Parágrafo Único. Para efeito do cálculo previsto neste artigo, ficam excluídos os Municípios nos quais o número de alunos atendidos pela rede municipal não corresponda a, pelo menos, $90 \%$ (noventa por cento) de sua capacidade mínima de atendimento".

${ }^{31}$ Lei estadual no 322/1996 (AMAPÁ): "Art. $2^{\circ}$ [...] $\S 4^{\circ}$ educação: relação entre o total de alunos atendidos, inclusive os alunos da pré-escola, e a capacidade mínima de atendimento pelo Município, publicada pela Secretaria de Estado da Educação até o dia 30 de abril de cada ano, relativamente aos dados do ano civil imediatamente anterior, calculada de acordo com Anexo II desta Lei, observado o disposto no Art. $2^{\circ}[\ldots]$ ".

Revista de Direito Brasileira | São Paulo, SP | v. 19 | n. 8 | p. 84- 106 |Jan./Abr. 2018 
Pernambuco $^{32}$, o critério de distribuição de receita baseia-se no número de matrículas e alunos na rede de ensino. No caso do estado do Ceará ${ }^{33}$, entretanto, os critérios levam em conta índices relacionados à qualidade da educação.

A histórica ineficiência do Estado em gerir a educação, principalmente no tocante à qualidade, requer que se explore o dever estatal de incentivo da educação com a colaboração da sociedade do art. 205 da Constituição (BRASIL, 1988) - instrumento constitucional alternativo pouco utilizado na prática.

Tal dever de promover a educação "incentivada com a colaboração da sociedade" pode ser explorado por meio do fenômeno da extrafiscalidade. Busca-se incentivar o investimento no ensino público escolar embasando-se no reconhecimento da extrafiscalidade como instrumento do Estado para a consecução de seus fins sociais.

Um critério ainda não explorado em prol da educação é a destinaçãolegal do produto de arrecadação de ICMS de forma proporcional ao investimento dos municípios na qualidade do ensino. Tal política pública permitiria aos municípios (mais frágeis na estrutura federativa) a adoção de uma atitude mais proativa na concessão de incentivos fiscais em prol no ensino público escolar, sem que isso acarretasse uma renúncia de receitas prejudicial às contas do ente municipal.

Uma decorrênciaessencialdo repasse de ICMS por lei estadual ${ }^{34}$ (art. 158, parágrafo único, II, CF) é a vinculação automática de parte desta receita do município à educação. Ressalta-se que, na base de cálculo de aplicação de impostos no desenvolvimento da educação, o $\S 1^{\circ}$ do art. 212 da CF não considera como receita do governo o montante que este é obrigado a transferir a título de repasses constitucionais (BRASIL, 1988).O caput do art. 212, no entanto, obriga o ente federativo beneficiário do repasse a incluir o valor deste na base de cálculo de aplicação de impostos no desenvolvimento da educação. Em efeitos práticos, o Estado não incluiria o valor do montante de ICMS a ser repassado pelos municípios nos $25 \%$ destinados ao fundo de educação. Uma vez repassados os valores de ICMS aos municípios, integrando a receita desses, surge a obrigação constitucional de incluir os novos valores repassados na base de cálculo do fundo de educação - inclusive aqueles decorrentes da lei estadual mencionada.

Formar-se-ia, de tal forma, um círculo virtuoso: o município que aumentasse seus investimentos na educação pública seria premiado com aumento de repasses de ICMS, sendo que

\footnotetext{
${ }^{32}$ Lei estadual $n^{\circ}$ 10.489/1990 (PERNAMBUCO): “Art. $2^{\circ}$ [...] 2.4. $2 \%$ (dois por cento), a serem distribuídos com base no critério relativo à área de Educação, considerando-se a participação relativa do número de alunos matriculados no ensino fundamental em escolas municipais, com base no resultado do censo escolar anual, publicado por meio de portaria do Ministério da Educação; [...]".

${ }^{33}$ Lei estadual no 12.612/1996 (CEARÁ): “Art. $1^{\circ}$ [...] II - 18\% (dezoito por cento) em função do Índice Municipal de Qualidade Educacional de cada município, formado pela taxa de aprovação dos alunos do $1^{\circ}$ ao $5^{\circ}$ ano do ensino fundamental e pela média obtida pelos alunos de $2^{\circ}$ e $5^{\circ}$ ano da rede municipal em avaliações de aprendizagem; $[\ldots] "$.

${ }^{34}$ A Suprema Corte possui o entendimento pacífico de que, diferentemente dos $3 / 4$ do repasse de ICMS aos municípios (CF, artigo 161, I), a regulamentação do artigo 158, parágrafo único, inciso II, faz-se por lei ordinária estadual. Citam-se trechos da ementa do acordão: "EMENTA: AÇÃO DIRETA DE INCONSTITUCIONALIDADE. PRELIMINARES. LEI ESTADUAL. ICMS. PARCELA PERTENCENTE AOS MUNICÍPIOS. CÁLCULO. VALOR ADICIONADO. MATÉRIA RESERVADA À LEI COMPLEMENTAR. VÍCIO FORMAL INSANÁVEL. [...] 3. ICMS. Distribuição da parcela de arrecadação que pertence aos Municípios. Lei estadual que disciplina a forma de cálculo do valor adicionado para apuração do montante fixado no inciso I do parágrafo único do artigo 158 da Constituição Federal. Matéria expressamente reservada à lei complementar (CF, artigo 161, I). Vício formal insanável que precede a análise de eventual ilegalidade em face da Lei Complementar federal 63/90. Violação direta e imediata ao Texto Constitucional. [...]. 5. Parcela relativa a um quarto da participação dos Municípios no produto da arrecadação do ICMS (CF, artigo 158, parágrafo único, inciso II). Matéria reservada à lei estadual. Afronta formal não configurada. Inexistência de desrespeito ao princípio da isonomia. Ação procedente em parte" (ADI 2728, Relator(a): Min. MAURÍCIO CORRÊA, Tribunal Pleno, julgado em 28/05/2003, DJ 20-02-2004 PP-00016 EMENT VOL-02140-02 PP-00218 RTFP v. 15, n. 72, 2007, p. 317-329).
}

Revista de Direito Brasileira | São Paulo, SP | v. 19 | n. 8 | p. 84 - 106 |Jan./Abr. 2018 
esses repasses aumentariam, inexoravelmente, o valor do fundo orçamentário vinculado à educação pública.

Denota-se, no entanto, que tal fenômeno somente ocorreria se o município investisse valores na educação fora daqueles valores já constitucionalmente destinados ao ensino público. Os municípios possuem o dever de aplicarem o mínimo de $25 \%$ de suas receitas de impostos no desenvolvimento do ensino, sob pena de sofrerem intervenção constitucional do Estado em sua gestão, prevista no inciso III do art. 35 da CF (BRASIL, 1988), ou até de responsabilização pessoal dos gestores por crime de responsabilidade ${ }^{35}$.

Enfrenta-se, por conseguinte, a seguinte questão: qual seria a amplitude da definição de "investimento no desenvolvimento do ensino" para fins de concessão do benefício ao município? $\mathrm{O}$ dispositivo legal somente abrangeria repasses financeiros diretos do município ao ensino público ou também englobaria incentivos que resultassem em renúncia de receita?

Levando-se em conta a essencialidade do ensino público escolar, a melhor interpretação de investimento na educação pública seria ampliativa- incluindo aqueles investimentos decorrentes de renúncia de receitas. Dessa forma, o Município poderia conceder incentivos fiscais e subvenções às entidades e pessoas jurídicas de direito privado que auxiliem na qualidade do ensino público escolar - induzindo uma cultura de colaboração da sociedade com o desenvolvimento do ensino.

Questiona-se ainda: como enfrentar o instituto da renúncia de receitas nos casos de extrafiscalidade em favor do desenvolvimento do ensino? Para a Lei de Responsabilidade Fiscal (Lei Complementar no 101/2000), a regra geral é a instituição, previsão e efetiva arrecadação de todos os tributos do ente. A renúncia de receita encontra-se no campo da excepcionalidade (PALUDO, 2013, p. 255).

A renúncia, em regra, deve ser concedida mediante lei específica e, eventualmente, mediante convênio (PALUDO, 2013, p. 256). Segundo o art. 14 da LRF (BRASIL, 2000), a concessão ou ampliação de incentivo ou benefício de natureza tributária da qual decorra renúncia de receita deve: a) estar acompanhada de estimativa do impacto orçamentário-financeiro no exercício em que deva iniciar sua vigência e nos dois seguintes; b) atender ao disposto na Lei de Diretrizes Orçamentárias; e c) atender a pelo menos uma das seguintes condições: c.1) demonstração de que a renúncia foi considerada na estimativa de receita na lei orçamentária e que não afetará as metas de resultados fiscais previstas na LDO; c.2) estar acompanhada de medidas de compensação nos dois exercícios seguintes, por meio do aumento de receita (no exercício da concessão basta o demonstrativo do item ' $a$ ').

Esse aumento de receita poderia ocorrer mediante as seguintes medidas: elevação de alíquotas, ampliação da base de cálculo e majoração ou criação de tributo ou contribuição. Nos casos de medida de compensação por aumento de receita, o benefício fiscal concedido só poderá entrar em vigor após implementadas as medidas para o aumento da arrecadação(BRASIL, 2000).

Com o escopo de fornecer mais segurança jurídica na seara dos benefícios fiscais regionais e locais, justifica-se a regulamentação das renúncias de receitas por meio de Lei de Responsabilidade Fiscal Estadual. Tal possibilidade seria decorrência lógica do inciso I do art. 24 da Constituição (BRASIL, 1988), que atribui competência legislativa concorrente acerca de direito financeiro à União, Estados e Distrito Federal. A LRF estadual serviria para cobrir as lacunas da ausência das normas gerais da União sobre as peculiaridades regionais e locais ( $\S 2^{\circ}$ e $3^{\circ}$ do art. 24 da $\mathrm{CF}$ ). O texto regulamentaria as relações entre os diferentes poderes e instituições, ampliação da transparência das contas públicas e a exigência de avaliação de renúncias fiscais.

\footnotetext{
${ }^{35}$ Segundo o art. $1^{\circ}$ do Decreto-Lei 201/1967, respondem por crime de responsabilidade os prefeitos e vereadores que cometerem ato de "empregar subvenções, auxílios, empréstimos ou recursos de qualquer natureza, em desacordo com os planos ou programas a que se destinam".
} 
A norma da Lei de Responsabilidade Fiscal Estadual somente viria a acrescer ao processo de conscientização financeira dos gestores municipais iniciada pela Lei complementar federal $101 / 2000^{36}$. Adicionalmente, haveria um estímulo à participação da comunidade nas decisões acerca da educação pública no orçamento anual, lei de diretrizes orçamentárias e plano plurianual, visando otimizar a aplicação da escassa receita pública municipal. Discutir-se-ia, em audiências e debates públicos, sobre aplicação de recursos públicos, renúncia de receitas e obtenção de novas fontes de custeio para a qualidade do ensino público local.Tais instrumentos de gestão democrática dos municípios possuem previsão legal no Estatuto da Cidade (Lei n. $10.257 / 2001)^{37}$.

Considerando a posição privilegiada em que se encontra a educação entre as prioridades e metas do Estado de Direito, defende-se a regulamentação diferenciada das normas referentes à renúncia de receitas em tal área - podendo apresentar requisitos fiscaisespecíficos, mas em conformidade com asdiretrizes da Lei de Responsabilidade Fiscal Federal ${ }^{38}$. A receita proveniente do repasse do ICMS educação seria a medida de compensação necessária para a concessão de tais incentivos fiscais. De tal forma, os Estados estariam induzindo os governantes locais a aplicarem mais recursos no desenvolvimento do ensino de forma segura, transparente e legítima.

Defende-se que tais instrumentos normativos teriam duas funções essenciais: compensatória e indutiva. No tocante à função compensatória, a transferência de receita de ICMS restabeleceria o equilíbrio das contas daquele município que aumentou investimentos ou renunciou de receitas tributárias por meio de benefícios e isenções fiscais em prol do ensino escolar público. Em relação à função indutiva, lograria induzir os Municípios a formularem e aplicarem verbas em programas locais que visem melhorar a qualidade ensino público escolar ${ }^{39}$.

A extrafiscalidade transforma-se, então, num importante instrumento para a atuação do Estado e dos Municípios na luta pelo desenvolvimento do ensino e garantia da dignidade humana.Não se defende uma extrafiscalidade irresponsável que poderia até prejudicar os alunos

\footnotetext{
${ }^{36}$ Sobre o processo de conscientização financeira dos gestores municipais após a lei de responsabilidade fiscal n. 101/2000 (CAMARGO, PEREIRA; SANTIN, 2017, p. 13): "Isto ocorre por meio da conscientização dada pela Lei de Responsabilidade Fiscal, à medida em que requer a participação da comunidade nas decisões do orçamento anual, lei de diretrizes orçamentárias e plano plurianual, com vista a otimizar a aplicação do recurso público, cada vez mais escasso. Assim, além das demais prerrogativas abertas, propõe que a sociedade como um todo participe deste processo (ver artigo 44 da Lei 10.257/2001), em sendo obrigatória a audiência pública para aprovação das peças orçamentárias municipais, sob pena de nulidade por vício formal no processo legislativo da lei municipal, além de improbidade administrativa do prefeito municipal (artigo 52 da Lei 10.257/2001)".

${ }^{37}$ Cita-se o texto da norma (BRASIL, 2001): "Art. 43. Para garantir a gestão democrática da cidade, deverão ser utilizados, entre outros, os seguintes instrumentos: [...] II - debates, audiências e consultas públicas; [...]”.

${ }^{38}$ Rejeita-se qualquer interpretação que leve à infundada hipertrofia das competências legislativas da União em detrimento dos demais entes federativos. Nota-se que o STF vem seguindo linha parecida. Segundo Luiz Fux no julgamento da ADI 2663/RS (rel. Min. Luiz Fux, julgamento em 8.3.2017): “Aprospectiveoverruling, antídoto ao engessamento do pensamento jurídico, possibilita ao STF rever sua postura em casos de litígios constitucionais em matéria de competência legislativa, viabilizando o prestígio das iniciativas regionais e locais, ressalvadas as hipóteses de ofensa expressa e inequívoca a norma da Constituição".

${ }^{39}$ Faz-se aqui uma analogia com as funções da técnica de repasse do ICMS ecológico (RAMALHO, PASSOS, 2014, p. 9): "Analisado o contexto histórico em que se deu a concepção do ICMS-E no Estado da Paraná, sua feição original e a evolução normativa percebida no decorrer de sua implantação em outros 12 (doze) Estados federativos, é seguro concluir que, nos moldes atuais, tal instituto se predispõe ao cumprimento de duas funções essenciais: compensatória e indutiva. Pela primeira (compensatória) - única visada quando de sua concepção -, oICMS-E se propõe a restabelecer o equilíbrio econômico entre os Municípios de um mesmo Estado, reparando o prejuízo daqueles que sofrem restrições de uso de seu território, por força da existência de áreas de proteção ambiental. No exercício da função indutiva, que melhor o caracteriza atualmente, o ICMS-E é posto a serviço da política de proteção ambiental do Estado, que, mediante promessa de incremento de receitas tributárias, logra induzir os Municípios a formularem e aplicarem programas que privilegiem a conservação ambiental, o desenvolvimento sustentável, o saneamento ambiental e a elevação de seus indicadores sociais".
}

Revista de Direito Brasileira | São Paulo, SP | v. 19 | n. 8 | p. 84 - 106 |Jan./Abr. 2018 
da rede pública de ensino, mas sim um plano de ação articulada entre diversos entes federativos, favorecendo o desenvolvimento da pessoa enquanto cidadã e profissional qualificada.

Essa análise de custo-benefício deverá reger a decisão política do país no desenvolvimento do ensino, sempre em respeito à dignidade da pessoa humana, justiça social, responsabilidade fiscal, desenvolvimento sustentável e demais princípios fundamentais que regem o Estado Social Democrático de Direito.

\section{NOTAS CONCLUSIVAS}

Os problemas da educação pública são conhecidos no cenário brasileiro - vão desde a ausência de universalização do atendimento no ensino escolar público até os notórios problemas na qualidade da educação.

No plano internacional, a Declaração Universal de Direitos de 1948 (ASSEMBLEIA GERAL DAS NAÇÕES UNIDAS, 1948), em seu artigo 26, já concebia o direito à instrução na sua conotação clássica individual, acoplando-lhe, também, uma finalidade social. No plano interno, a Constituição brasileira incorporou os preceitos fundamentais básicos da educação no caput do art. $6^{\circ}$ e em algumas normas do capítulo III do título da Ordem Social (arts. 205 e seguintes da $\mathrm{CF}$ ). Ressalta-se a fundamentalidade material de tais normas, permitindoinclusive a sua classificação como cláusulas pétreas.

A Constituição (BRASIL, 1988) outorga competências materiais e legislativas de forma concorrente para os sistemas de ensino da União, dos Estados e dos Municípios (art. 211). Tal instituto constitucional é chamado de federalismo de cooperação - que consiste no dever constitucional de a União, Estados e Municípios atuarem conjuntamente para atingir os fins sociais do Estado Democrático de Direito.

A extrafiscalidade em prol da educação busca seu fundamento no art. 170 da Constituição Federal. A ordem econômica, fundada na valorização do trabalho humano e na livre iniciativa, objetiva a concreção da dignidade da pessoa humana e da justiça social. Legitima-se a intervenção do Estado na economia, logo, para assegurar o direito indisponível à educação de qualidade, incentivando a colaboração da sociedade para a obtenção do pleno desenvolvimento da pessoa cidadã e qualificada para o mercado de trabalho (art. 205 da Constituição).

Uma ferramenta importante para o custeio da educação é o repasse legal de verbas de ICMS para o ensino público escolar, na forma do art. 158, parágrafo único, II, da Constituição Federal (BRASIL, 1988). A figura do "ICMS educacional" ou "ICMS educação" não é uma figura inédita na legislação do país. A educação aparece como critério para divisão do ICMS em estados como Ceará, Minas Gerais, Pernambuco e no Amapá. Nos casos de Minas Gerais, Amapá e Pernambuco, o critério de distribuição de receita baseia-se no número de matrículas e alunos na rede de ensino. No caso do estado do Ceará, entretanto, os critérios levam em conta índices relacionados à qualidade da educação.

Um critério ainda não explorado em prol da educação é a destinação do produto de arrecadação de ICMS de forma proporcional ao investimento dos municípios na qualidade do ensino. Tal política pública permitiria aos municípios (mais frágeis na estrutura federativa) a adoção de uma atitude mais proativa na concessão de incentivos fiscais em prol no ensino público escolar, sem que isso acarretasse uma renúncia de receitas prejudicial às contas do ente municipal.

Considerando a essencialidade do ensino público escolar, o investimento no ensino público escolar seria interpretado de forma ampliativa - abrangendo inclusive os investimentos decorrentes de renúncia de receitas. Desta forma, o Município poderia conceder incentivos fiscais e subvenções a entidades e pessoas jurídicas de direito privado que auxiliem na qualidade do ensino público escolar - induzindo uma cultura de colaboração da sociedade com o desenvolvimento do ensino. Adicionalmente, haveria um estímulo à participação da comunidade nas decisões acerca da educação pública no orçamento anual, lei de diretrizes orçamentárias e 
plano plurianual, visando otimizar a aplicação da escassa receita pública municipal. Discutir-seia, em audiências e debates públicos, sobre aplicação de recursos públicos, renúncia de receitas e obtenção de novas fontes de custeio para a qualidade do ensino público local. Tais instrumentos de gestão democrática dos municípios possuem previsão legal no Estatuto da Cidade (Lei $\mathrm{n}^{\circ}$ $10.257 / 2001)$.

Com o escopo de fornecer mais segurança jurídica na seara dos benefícios fiscais regionais e locais, justifica-se a regulamentação das renúncias de receitas por meio de Lei de Responsabilidade Fiscal Estadual. A LRF estadual serviria para cobrir as lacunas da ausência das normas gerais da União sobre as peculiaridades regionais e locais ( $\$ 2^{\circ}$ e $3^{\circ}$ do art. 24 da $\mathrm{CF}$ ). $\mathrm{O}$ texto regulamentaria as relações entre os diferentes poderes e instituições, ampliação da transparência das contas públicas e a exigência de avaliação de renúncias físcais.

Haja vista a posição privilegiada em que se encontra a educação entre as prioridades e metas do Estado de Direito, defende-se a flexibilização das normas referentes à renúncia de receitas em tal área - podendo apresentar requisitos distintos daquelas insertas na Lei de Responsabilidade Fiscal Federal. O respeito ao preceito do equilíbrio fiscal, no entanto, deve ser preservado.A receita proveniente do repasse do ICMS educação seria a medida de compensação necessária para a concessão de tais incentivos fiscais. De tal forma, os Estados estariam induzindo os governantes locais a aplicarem mais recursos no desenvolvimento do ensino de forma segura, transparente e legítima.

Por fim, destaca-se que o artigo possui o escopo de defender novas políticas de financiamento da educação em adição às já existentes. Nesse sentido, as políticas fiscal e econômica do país devem sempre buscar o interesse público primário, nele compreendidos a dignidade da pessoa humana, o pleno desenvolvimento do indivíduo e a educação de qualidade.

Mesmo o interesse arrecadatório do Estado pode e deve abrir espaço para a tutela da educação pública de qualidade quando for o caso. A própria viabilidade da vida humana no planeta depende de ações positivas do Estado em prol da educação e, consequentemente, do desenvolvimento sustentável. No trabalho proposto, além da extrafiscalidade, defende-se o federalismo de cooperação para a tutela dos direitos fundamentais da pessoa humana.

\section{REFERÊNCIAS BIBLIOGRAFICAS}

AMAPÁ. Lei estadual n. 322 de 23 de dezembro de 1996. Define critérios para distribuição da parcela de receita do produto e arrecadação do Imposto Sobre Operações Relativas à Circulação de Mercadorias e sobre Prestações de Serviços de Transporte Interestadual e Intermunicipal e de Comunicação - ICMS, pertencente aos municípios e dá outras providências. Macapá, Assembleia Legislativa, $1996 . \quad$ Portal online. Disponível em: <http://www.al.ap.gov.br/pagina.php?pg=buscar_legislacao>. Acesso em: 12 mar. 2018.

ASSEMBLEIA GERAL DAS NAÇÕES UNIDAS (ONU). Declaração Universal dos Direitos Humanos. Paris. 10 de dezembro de 1948. Disponível em: <http://www.onu.org.br/img/2014/09/DUDH.pdf >. Acesso em: 15 out. 2017.

A Agenda 2030 para o Desenvolvimento Sustentável. 2015. Disponível em: <https://nacoesunidas.org/wp-content/uploads/2015/10/agenda2030-pt-br.pdf>. Acesso em: 15 out. 2017.

BRASIL. Constituição da República Federativa do Brasil de 1988. Brasília, Senado Federal, 1988. Portal Online. Disponível em: <http://www.planalto.gov.br/ccivil_03/constituicao/constituicaocompilado.htm>. Acesso em: 15 out. 2017. 
. Decreto-Lei 201 de 27 de fevereiro de 1967. Brasília, Presidência da República, 1967. Disponível em: <http://www.planalto.gov.br/ccivil_03/decreto-lei/Del0201.htm>. Acesso em: 15 out. 2017.

.Lei complementar estadual $\mathrm{n}^{\circ} 57$ de 1991. Campo Grande, Mato Grosso do Sul. Disponível em: <http://www.imasul.ms.gov.br/wp-content/uploads/sites/74/2017/02/LEICOMPLEMENTAR-N\%C2\%BA-57-DE-04_01_1991.pdf>. Acesso em: 15 out. 2017.

Lei. 9394 de 20 de Dezembro de 1996. Estabelece as Diretrizes e Bases da Educação Nacional. Brasília, 1996. Disponível em: <http://www.planalto.gov.br/ccivil_03/leis/L9394.htm>. Acesso em: 15 out. 2017.

. Lei Complementar n. 101, de 4 de maio de 2000. Lei de Responsabilidade Fiscal. Presidência da República. Portal Online. Disponível em: <http://www.planalto.gov.br/ccivil_03/leis/LCP/Lcp101.htm>. Acesso em: 15 out. 2017.

. Lei n. 10.257 de 10 de Julho de 2001. Estatuto da Cidade. Presidência da República. Portal Online. Disponível em: <http://www.planalto.gov.br/ccivil_03/leis/LEIS_2001/L10257.htm>. Acesso em: 15 out. 2017.

. Lei n. 11.096 de 13 de Janeiro de 2005 - institui o Programa Universidade para TodosPROUNI; regula a atuação de entidades beneficentes de assistência social no ensino superior; altera a Lei N 10.891, de 9 de julho de 2004; e dá outras providências. Presidência da República. Portal Online. Disponível em: <http://www.planalto.gov.br/ccivil_03/_ato20042006/2005/lei/111096.htm>. Acesso em: 15 out. 2017.

. Supremo Tribunal Federal. Ação Direta de Inconstitucionalidade (ADI) 2.728, Tribunal Pleno, Relator(a): Min. Maurício Corrêa, , julgado em 28/05/2003, DJ 20-02-2004, 2007, Brasília, DF, p. 317-329. em:<http://www.stf.jus.br/portal/jurisprudencia/listarJurisprudencia.asp?s1=\%28ADI\%29\%2827 28\%2ENUME\%2E+OU+2728\%2EACMS\%2E\%29\%28PLENO\%2ESESS\%2E\%29\&base=base Acordaos\&url=http://tinyurl.com/y7xjaz5c>. Acesso em: 05 out. 2017.

Supremo Tribunal Federal. Ação Direta de Inconstitucionalidade (ADI) 2.663, Tribunal Pleno, Relator(a): Min. Luiz Fux, julgado em 8/3/2017, Brasília, DF. Disponível em:<http://www.stf.jus.br/portal/jurisprudencia/listarJurisprudencia.asp?s1=\%28ADI\%29\%2826 63\%2ENUME\%2E+OU+2663\%2EACMS\%2E\%29\&base=baseAcordaos\&url=http://tinyurl.com /yartvjwj>. Acesso em: 05 out. 2017.

BOBBIO, Norberto. A era dos direitos. Rio de Janeiro: Campus, 1992.

BRAUNER, Yariv et al. The future of tax incentives for developing countries. In: Tax, Law and Development.Edward Elgar Cheltenham, ReinoUnido/ Northampton, MA, EUA. 2013. p. 25-56.

CAGGIANO, Monica Hermann S. A educação: direito fundamental. In: RANIERI, Nina Beatriz Stocco. Direito à Educação: aspectos constitucionais. São Paulo: EDUSP, 2009, p. 23.

CEARÁ. Lei estadual n. 12.612 de 7 de agosto de 1996. Define critérios para distribuição da 
parcela de receita do produto e arrecadação do Imposto Sobre Operações Relativas à Circulação de Mercadorias e sobre Prestações de Serviços de Transporte Interestadual e Intermunicipal e de Comunicação - ICMS, pertencente aos municípios e dá outras providências. Fortaleza, Assembleia Legislativa, 1996. Portal online. Disponível em: https://www.al.ce.gov.br/index.php/atividades-legislativas/leis. Acesso em: 12 mar. 2018.

COMISSÃO MUNDIAL SOBRE MEIO AMBIENTE E DESENVOLVIMENTO (CMMAD). Nosso futuro comum. Rio de Janeiro: Fundação Getulio Vargas, 1988. Disponível em: <http://www.inbs.com.br/ead/Arquivos\%20Cursos/SANeMeT/RELAT\%23U00d3RIO\%20BRU NDTLAND\%20\%23U201cNOSSO\%20FUTURO\%20COMUM\%23U201d.pdf>. Acesso em: 12 nov. 2017.

COSTA, Regina Helena. Curso de direito tributário: Constituição e Código Tributário Nacional. 4. ed. São Paulo : Saraiva, 2014.

DIAS, Eduardo Rocha; LEITÃO, André Studart; FREITAS, Brenda Barros. Inclusão excludente, assistência, educação e paternalismo. Revista de Direito Brasileira, v. 17, n. 7, p. 306-327, 2017.

ELALI, André. Tributação e regulação econômica: um exame da tributação como instrumento de regulação econômica na busca da redução das desigualdades regionais. São Paulo: MP Editora, 2007.

FERREIRA FILHO, Manoel Gonçalves. Comentários à Constituição Brasileira de 1988. São Paulo: Saraiva, 1999.

FURTADO, Marcelo Gasque. Padrão de qualidade de ensino. In: RANIERI, Nina Beatriz Stocco (coord); RIGHETTI, Sabine (org.). Direito à educação. São Paulo: EDUSP, 2009.

FRANZESE, Cibele. Federalismo cooperativo no Brasil: da Constituição de 1988 aos sistemas de políticas públicas. 2010. Tese de Doutorado. Disponível em: <http://bibliotecadigital.fgv.br/dspace/handle/10438/8219>. Acesso em: 15 out. 2017

GOUVEA, Marcus de Freitas. A extrafiscalidade no direito tributário. Belo Horizonte: Del Rey, 2006.

INEP. Instituto Nacional de Estudos e Pesquisas Educacionais Anísio Teixeira. Censo escolar da educação básica 2016. Disponível em: <http://download.inep.gov.br/educacao_basica/censo_escolar/notas_estatisticas/2017/notas_estati sticas_censo_escolar_da_educacao_basica_2016.pdf>. Acesso em: 06 out. 2017.

MACHADO, Hugo de Brito. Curso de direito tributário. 26ª ed. São Paulo: Malheiros,2005.

MARTINS, James; TEODOROVICZ, Jeferson. Rumo a extrafiscalidade socioambiental. Anais do IX Simpósio Nacional de Direito Constitucional, 2010, p. 170-199.

MENDES, Gilmar Ferreira. Curso de direito constitucional. 10ª ed. São Paulo: Saraiva, 2015. 
MINAS GERAIS. Lei estadual n. 18.030, de 12 de janeiro de 2009. Define critérios para distribuição da parcela de receita do produto e arrecadação do Imposto Sobre Operações Relativas à Circulação de Mercadorias e sobre Prestações de Serviços de Transporte Interestadual e Intermunicipal e de Comunicação - ICMS, pertencente aos municípios e dá outras providências. Belo Horizonte, Assembleia Legislativa, 2009. Portal online. Disponível em: <http://leisestaduais.com.br/mg>. Acesso em: 12 mar. 2018.

NABAIS, José Casalta. O dever fundamental de pagar impostos: contributo para a compreensão constitucional do estado fiscal contemporâneo. 1998. Tese (Doutorado em Direito) Universidade de Coimbra, Coimbra.

. Política fiscal, desenvolvimento sustentável e luta contra a pobreza. Cadernos da Escola de Direito e Relações internacionais da UniBrasil, Curitiba, v. 1, n. 7, p. 361-378, 2007.

PALUDO, Augustinho Vicente. Orçamento público e administração financeira e orçamentária e LRF. $4^{\text {a }}$ ed. Rio de Janeiro: Elsevier, 2013.

PERNAMBUCO. Lei estadual n. 10.489 de 2 de outubro de 1990. Define critérios para distribuição da parcela de receita do produto e arrecadação do Imposto Sobre Operações Relativas à Circulação de Mercadorias e sobre Prestações de Serviços de Transporte Interestadual e Intermunicipal e de Comunicação - ICMS, pertencente aos municípios e dá outras providências. Recife, Assembleia Legislativa, 1990. Portal online. Disponível em: <http://legis.alepe.pe.gov.br/>. Acesso em: 12 mar. 2018.

PIRES, Adilson Rodrigues. Ligeiras reflexões sobre a questão dos incentivos fiscais no Brasil. In: MARTINS, I. G.; ELALI, A.; PEIXOTO, M. (Coord.). Incentivos fiscais. Questões pontuais nas esferas federal, estadual e municipal. São Paulo: MP Editora., 2007.

PORTUGAL. Constituição da República Portuguesa. Lisboa, Parlamento. 25 de Abril de 1976. Portal Online. Disponível em: 〈https://www.parlamento.pt/parlamento/documents/crp1976.pdf〉. Acesso em: 15 out. 2017.

PEQUENO, Marconi. O fundamento dos direitos humanos. Educando em direitos humanos, p. 25, 2016.

RAMALHO, Leila Von Söhsten; PASSOS, Rosana Maciel Bittencourt. A eficácia doICMS ecológico como instrumento de política ambiental e o Dever do estado quanto a sua efetivação. Artigo publicado na Revista da Procuradoria Geral do Estado da Bahia. 2014. Disponível em: $<$ http://anape.org.br/site/wp-

content/uploads/2014/01/006_090_Leila_von_Shsten_Ramalho_22072009-17h09m.pdf >.Acesso em: 15 out. 2017.

ROCASOLANO, Maria Mendez; SILVEIRA, Vladmir Oliveira da. Direitos Humanos: conceitos, significados e funções. São Paulo: Saraiva, 2010.

RODRIGUES, Hugo Thamir; MULLER, Eli Carla da Silva. Políticas tributárias municipais de incentivos fiscais: extrafiscalidade e o direito humano fundamental ao meio ambiente sustentável - instrumentalização para o desenvolvimento e para a inclusão social. Revista do Direito, Santa Cruz do Sul, n. 38, p. 26-49, 2012. 
ROTHBARD, Murray Newton. Education: Free and compulsory. Ludwig von Mises Institute, 1979.

SANTIN, Janaína Rigo; DA SILVA PEREIRA, André; DE CAMARGO, Evandro José Bilycz. Administração pública municipal e lei de responsabilidade fiscal: gastos e receitas públicas. Revista de Direito Brasileira, v. 17, n. 7, p. 108-124, 2017.

SARLET, Ingo Wolfgang. A eficácia dos direitos fundamentais: uma teoria geral dos direitos fundamentais na perspectiva constitucional. 12a ed. Porto Alegre: Livraria do Advogado Editora, 2015.

SCHULTZ, Theodore W. Investindo no povo. Rio de Janeiro: Forense Universitária, 1987.

SILVA, José Afonso da. Comentário Contextual à Constituição. 2a ed. São Paulo: Malheiros, 2006.

TEIXEIRA, Evandro Camargos. Dois ensaios acerca da relação entre criminalidade e educação. 2011. Tese de Doutorado. Universidade de São Paulo. 